\title{
THE INFLUENCE OF THIN CAPITALIZATION AND THE EXECUTIVES' CHARACTERISTICS TOWARD TAX AVOIDANCE BY MANUFACTURERS REGISTERED ON ISE IN 2011-2015
}

\author{
Dewi Prastiwi \\ Universitas Negeri Surabaya \\ dewiprastiwi@unesa.ac.id \\ Renni Ratnasari \\ Universitas Negeri Surabaya \\ renniratnasari.28@gmail.com
}

Received: August, 2018

Reviewed: April, 2019

Accepted: April, 2019

\section{ABSTRACT}

This study aims to analyze the effect of thin capitalization and executives' characteristics based on tax avoidance. The sample consists of 38 manufacturing companies listed on the Indonesia Stock Exchange in 2011-2015 and they will be determined by several criteria. The results of multiple regression analysis shows that the thin capitalization and executives' characteristics positively affect tax avoidance. These results are consistent with the view that companies tend to increase interest of their debt (thin capitalization) to minimize the tax burden and the executives' characteristics has an important role in the action.

Keywords: Executives' Characters, Tax Avoidance, Thin Capilatization.

How to cite: Prastiwi, D \& Ratnasari, R. (2019). The Influence Of Thin Capitalization And The Executives' Characteristics Toward Tax Avoidance By Manufactures Registered On ISE In 2011-2015. Akrual: Jurnal Akuntansi. 10 (2): 119-134. doi: http://dx.doi.org/10.26740/jaj.v10n2.p119-134

\section{INTRODUCTION}

Tax is a fixed expense of a company, reducing the amount of income and, thus, it is not surprising if various efforts are conducted both legally and illegally for tax saving. The effort to minimize tax in legal mean is oftenly called tax planning or tax sheltering (Suandy, 2016:1)According to Zain (2008:67) tax avoidance is one of the tax planning actions that can be executed through the profit processing to reduce the amount of tax imposition that the company does not want. In addition, research by Butje dan Tjondro (2014) argues tax avoidance is an act of obtaining profit by utilizing the weakness of tax law to reduce the amount of tax due. Those that have been proven to commit tax avoidance are not always wrong since there are many provisions in taxation that encourage the companies to reduce their tax due and additionally there is a vague existence of tax restrictions (gray area), especially for all transactions deemed as complex (Dyreng et al., 2010).

The tax avoidance phenomenon was revealed in 2016, with the release of an investigative document called Panama Papers. The document is processed by ICIJ (International Consortium of Investigative 
AKRUAL: Jurnal Akuntansi, volume 10, issue 2, April 2019 (119-134)

Journalist) containing 11.5 million investigation results of 214,000 multinational companies including shareholders and company directors. It reveals the involvement of world important people by conducting offshore company business agreements in order to hide their assets (Sudiarta, 2016).

In term of Panama Papers, ICIJ has previously released similar documents such as Swiss Leaks (2015) concerning Swiss HSBC Bank case which allegedly helped its customers in 203 countries to avoid tax payment obligations with an aggressive tax reduction scheme in their country of origin, especially in Europe with total value of US\$ 119 billion. According to Swiss Leaks data, Indonesia ranked 95th country involved in the tax evasion case with value of US \$ 134.1 million (Deddy, 2015).

Table 1. 91-100 Ranked Countries in Swiss Leaks Case (in USD millions)

\begin{tabular}{cll}
\hline Rank & \multicolumn{1}{c}{ Country } & Value \\
\hline 91 & Palestine & 148.9 \\
92 & Madagascar & 146.3 \\
93 & Peru & 141.2 \\
94 & Mauritius & 141.0 \\
95 & Indonesia & 134.1 \\
96 & Sudan & 131.0 \\
97 & Hungary & 122.5 \\
98 & Latvia & 121.8 \\
99 & Chad & 120.7 \\
100 & Tanzania & 114.0 \\
\hline
\end{tabular}

Data Source: Projects ICIJ, 2015 (processed by authors)

Based on the number of customers about 100 customers recorded in the Swiss Leaks case (ICIJ, 2015), Indonesia ranked 74th. It can illustrate that state tax revenue continues to be 120 eroded due to the practice of profit shifting. International tax systems and differences in tax rates have caused the tax transfer scheme to increase. For example, attempt to exploit the weaknesses of Double Taxation Agreement (DTA) to minimize tax burden, manipulate transfer pricing, thin capitalization, etc. (Arifin, 2014).

One of the biggest losses in tax revenue is due to tax reduction on high debt level, driving many developed countries to adopt thin capilatization rules in their attempt to protect their state's tax base. Thin capitalization is the practice of tax avoidance through altering the debt structure to be larger than capital. This practice arises as a result of a tax regulation stating the difference between the treatment to interest as a return on debt and dividend as a return on return on stock investment. It is a condition that a multinational company especially having a special relationship will practice thin capitalization by increasing the amount of debt financing with high tax rates to gain benefit from the interest reduction on the basis of corporate tax imposition.

Government efforts to prevent this practice are issued on Article 18 paragraph (1) of Income Tax Law, which gives authority to the Minister of Finance in determining the amount of ratio between debt and company capital for tax calculation purposes. However, it has a lack of clarity in the determined comparative magnitude, causing the postponement of the regulation. In 2015, the government issued 
Regulation of Minister of Finance Number 169/PMK.010/2015 as a follow-up to the prevention of thin capitalization practice.

Taylor and Richardson (2012) analyze thin capitalization, multinationality and tax havens as independent variables in the scheme of international tax avoidance practices. The result proves that thin capitalization significantly influences tax avoidance. Thin capitalization uses countries with high tax rates to obtain tax incentives from the interest, while low tax rates are often used as fund by multinational companies by utilizing tax haven. Thin capitalization is a major trigger in multinational corporations' tax evasion attempts. However, a study conducted by Ismi dan Linda (2016) states that although many companies do thin capitalization, the results do not show any influence on tax avoidance. Hence, by this exposure the researchers want to retest the relationship between thin capitalization and tax avoidance.

In addition, the researchers also add an independent variable of executives' characteristics because the decision to implement thin capitalization depends on them. The statement that company executives have an important role in determining the tax avoidance scheme executed by the company is supported by a research conducted by Dyreng et al. (2010) and Budiman \& Setiyono (2013). A company executive's role has not only an abillity to add value to the company but also a tendency to support tax avoidance. One of the ways they do is to place trustworthy people with the expertise to observe and create the scheme according to the executives' expectation (Dyreng et al., 2010). Budiman and Setiyono (2013) argue the more the corporate executives possess any traits of risk takers, the higher the level of avoidance of the tax. Therefore, researchers want to test on the executives' characteristics whether it has a positive effect on tax avoidance.

Based on the phenomenon described above, the research tends to combine previous studes' variables (Taylor and Richardson, 2012; Ismi and Linda, 2016; Butje et al., 2014; Budiman et al., 2013; Dyreng et al., 2010). Tax avoidance is proxied by the composite result of Book Tax Difference (BTD), abnormal BTD and Tax Shelter (Taylor \& Richardson, 2012; Hanlon \& Heitzman, 2010; Desai et al., 2006).

This study employs all manufacturers listed on the IDX for the period 2011-2015 as its population. The population selection refers to the 2014 Bank Indonesia report, informing that the manufacturing sector ranked second largest recipient of foreign debt after the financial sector and contributed 30\% to the Gross Domestic Product (GDP). Meanwhile, the study chooses the period of 2011 until 2015 because in that period tax revenue underwent a reduction. Based on the background and elaboration of the results of previous studies, the authors tends to examine the effect of thin capitalization and executives' characteristics on tax avoidance behaviors. 


\section{LITERATURE REVIEW}

\section{Theory of Planned Behavior}

In accordance with Azwar (2013:9), psychology takes a look at human behavior as complex and simple reaction, in which a set of certain behaviors exists to be used by the individuals to survive.

Azwar (2013:12) also notes that the theory of behavior develops and is modified by Ajzen to be Theory of Planned Behavior (TPB). TPB explains that the behavior caused by an individual arises as there is an intention to behave. Meanwhile according to Ajzen in Azwar (2013:13) the emergence of intention to behave is determined by three factors, namely:

1. Behavioral Beliefs

They refer to notions individuals believe that there would be a result of a behavior and evaluation of certain activities.

\section{Normative Beliefs}

They consist of all normative expectations from others and motivation to fulfill those expectations.

3. Control Beliefs

Control Beliefs embody the existence of things considered to support or to inhibit a behavior that will be displayed, and also how strong an individual's perception regarding things that support and inhibit that behavior.

Regarding the study, the theory of planned behavior is relevant enough to explain taxpayers' behaviours in fulfilling tax obligation. Generally, before doing something, every individual will have confidence in the results obtained from 122 committing their behavior. Then they will make a decision to do it or not. This can be attributed to company policy in conducting tax planning. Taxpayers who perform their tax planning well can pay tax in a minimum amount of taxpayer awareness (behavioral beliefs).

\section{Thin Capitalization}

As one of tax avoidance schemes, thin capitalization is the practice of financing a larger number of company branches or subsidiaries by interest rather than using equity capital. The practice arises because of differences in tax treatment regarding loan interest and dividend. Interest cost is one of the deduction elements in the calculation of taxable income. Contrarily, dividend is not an element in term of reducing taxable income (Kurniawan, 2015:241).

Thin capitalization often happens caused by the reason of financing a subsidiary, whereby the parent company will contribute in the form of debt (not capital). Thus the subsidiary will be burdened with interest cost as a deduction from taxable income, and at last the amount of the subsidiary tax due would also decrease (Rahayu, 2010).

Income Tax Law in Indonesia has regulated thin capitalization, in article 18 paragraph (1). This article sets Minister of Finance has an authority to issue a decision regarding the magnitude of the ratio between the company debt and capital for the purposes of calculating taxable income as a tax basis paid under the Income Tax Law. Regarding its execution, Decree of the Minister of Finance 
Number 1002/KMK.04/1984 was issued. It stipulates the maximum ratio of debt and equity which is three compared to one $(3: 1)$ (Kurniawan, 2015:242).

However, the implementation of the Decree of Minister of Finance Number 1002/KMK.04/1984 subsequently underwent suspension for the release of the Decree of Minister of Finance No. 254/KMK.1/1985. It occured as there were concerns that could obstruct the development of businesses in Indonesia.

In 2015, the government reissued regulations relating to the ratio of debt and capital due to the increasing number of tax avoidance practices in Indonesia by utilizing corporate financing through debt. Minister of Finance Regulation Number 169/PMK.010/2015 states that:

1. The highest debt to equity ratio as mentioned in article 1 paragraph 1 is set $4: 1$.

2. Excluded from such provision is:

a. Banking taxpayer

b. Funding institution taxpayer

c. Insurance and reinsurance taxpayer

d. Oil and gas mining, general mining and other mining taxpayer which are bound in sharing contract, work contract or joint mining working agreement, and such contract or agreement require a specific debt to equity ratio; and

e. Taxpayer whose all income is subject to final income tax under tax law and regulation, and

\section{f. Taxpayer in infrastructure business.}

\section{Executives' Characteristics}

Executives are individuals who have important positions in leadership system in a company or an organization. They have a goal to achieve the company vision by giving influence on all company aspects so that it plays a big role on decision making, even the risky one.

Low (2006) states, during performing its obligations, a company leader usually has two different characteristics in decision making, namely risk taker and risk averse. Executives with risk taker traits have more courage in taking risky business decisions with big profits for the company. Meanwhile, those with risk averse characteristics will tend to dislike risk so that they possess less courage in taking a big business decision. Risk is always related to the profits that will be obtained by the company, in which the risk could be interpreted as a deviation from the income that will be received by the company. The greater the income deviation is, the greater the risk would arise. Investors must face opportunities or possibilities emerging from differences in expected results with results that actually occur (Penman et al., 2007).

Similarly, Paligorova (2010) defines corporate risk as the volatility of corporate earnings proxied by the standard deviation formula. Based on this statement, it can be concluded the company risk is a standard deviation or deviation from profit, and the deviation could be considered less or more than what has been planned by the company. The 
greater amount of income deviation would be directly proportional to the greater risk a company will face. How big or small the risk is would indicate the executives' traits are included either in the category of risk taker or risk averse (Budiman et al.,2013).

\section{Tax Avoidance}

State revenue from the tax sector is the biggest source for State Budget (APBN), compared to other revenue sources such as non-tax revenues and grants. In Indonesia, taxation adheres to self assessment tax collection system, whereby each of taxpayers has an authority to calculate, pay and report their own taxes. Therefore, honesty and taxpayer compliance in completing their obligations are highly needed. However, most taxpayers have desire to minimize tax obligation in various ways, either in a way that still fulfills the provisions of taxation (lawful) and ways that clearly violate tax regulations (unlawful). Taxpayers' attempts of minimizing tax obligations but still following taxation provisions are considered tax avoidance (Suandy, 2016:8).

Tax avoidance is an effort made to reduce taxes, yet the doer still obeys tax regulations such as by utilizing exception and tax deduction that are not prohibited, or by delaying taxes through all transactions not regulated in the tax regulations (Budiman and Setiyono 2013). Jacob (2014) also defines tax avoidance as an intentional act by reducing tax liability from the amount that should be paid to the tax authority through efficient planning by taking advantage of loopholes within tax provisions.
Tax avoidance does not mean that you are completely free from costs. Taxpayers are still taxed with several costs such as the cost of time and energy sacrificed to avoid the tax, and also, there are a number of risks will be borne for the disclosure of tax evasion. These would damage the reputation - the company can loose it at severe, and long-term business continuity (Ngadiman and Puspitasari, 2014).

The Committee of Fiscal Affairs from EOCD in Suandy (2016:8) states there are three traits of tax avoidance, which are:

1) There is an artificial element, in which various kinds of rules are made as if they exist yet they do not, and it happens because there is no any tax rule stipulating.

2) The use of loopholes from the Law by stipulating legal provisions in order to achieving certain objectives, which is not the actual purpose intended by the legislator.

3) Utilizing consultant service to perform tax evasion by means or methods that meet the requirements of taxpayers.

There are some of means executed by companies due to tax avoidance, as follows:

1. Transferring the subject and/or tax object to a country that has tax or tax relief facility or by selecting a substantive tax planning.

2. Strengthening the economic substance of a transaction through formal tax planning that can provide the lowest tax expense.

3. Utilizing the provisions of anti-tax avoidance over transfer pricing, thin capitalization, treaty shopping and controlled foreign 
corporation (spresific anti avoidance rules), and other transaction which has no any business substance (general anti avoidance rules).

\section{Hypothesis Development}

The Influence of Thin Capitalization to Tax Avoidance

Double tax agreement is used as a scheme to divert corporate profits by financing companies through debt (thin capitalization). Rahayu (2010) defines thin capitalization as a loan in the form of money or capital from shareholders by financing its subsidiaries, a holding company will contribute in the form of debt (not capital). Hence, the subsidiary will be burdened with the interest expense which is a deduction element in the calculation of Taxable Income, and eventually, subsidiary tax due is also reduced.

A study conducted by Taylor and Richardson (2012) uses thin capitalization as one of its independent variables in the international tax avoidance mechanism. It is called as thin capitalization as companies will generally increase interest-based debt and it causes the capital becoming small. The result of the research proves that a number of companies with large debt structure tend to commit tax avoidance. To test thin capitalization for tax avoidance, the following hypothesis is formulated:

H1: Thin capitalization positively affect tax avoidance.

\section{The Influence of Executives' Characteristics to Tax Avoidance}

Corporate executives play a very important role in determining the tax avoidance scheme in a company. It is strengthened by a research conducted by Dyreng et al. (2010) and Budiman \& Setiyono (2013). The company executives' role is not only able to add value to the business but also has a tendency to support tax avoidance.

One of attempts executives choose is to place trustworthy people with the expertise to observe and create tax avoidance schemes according to the executives' expectation (Dyreng et al., 2010). Budiman and Setiyono (2013) stated that the more corporate executives are considered risk takers, the higher the level of tax avoidance would be. To test the executives' characteristics against tax avoidance, it is formulated through the following hypothesis:

H2: Executives' characteristics positively influence tax avoidance.

\section{RESEARCH METHODS}

\section{Research Approach}

The study employs quantitative research as the approach method, as it aims to test a predetermined hypothesis (Sugiyono, 2015:8). The data sources are in the form of audited financial statements from all manufacturers listed on the Indonesia Stock Exchange (IDX) in 2011-2015 accessed from its official website (www.idx.co.id).

\section{Population and Sample}

The population consists of all manufacturing 
companies listed on IDX Fact Book since January 2016. The sampling method used was purposive sampling. Pusposive sampling is a method by taking samples from the population based on certain criteria (Hartono, 2013:61). The research sample has been selected in accordance with the following criteria:

1. The company is registered on IDX in 20112015.

2. The company publishes complete audited financial statements during the study period.

3. The company has a pre-tax amount above 0 (no loss)

4. The company has no fiscal loss. It causes the company not to be taxed since taxable profit is used to reduce the amount of fiscal loss in the previous year.

5. The company has positive effective tax rate.

6. The company has complete data which are needed in the study.

Regarding to all criteria, the study obtains 38 companies as the sample for per year.

\section{Research Variables and Operational Definition}

The dependent variable used is tax avoidance. Tax avoidance is defined as an effort to reduce taxes legally, meaning that they still strive to comply with the provisions of taxation regulations. Tax avoidance (TAVO) is measured by using a composite of Book Tax Difference (BTD), Abnormal BTD and Tax Shelter (Taylor \& Richardson, 2012; Hanlon dan Heitzman, 2010; Desai et al., 2006).

\section{Book Tax Difference (BTD)}

It is the difference between reported income before tax (commercial income) and taxable income (fiscal profit) of company $\mathrm{i}$ in year $\mathrm{t}$ divided by total asset belonging to company $\mathrm{t}-1$. BTD measurement refers Hanlon and Heitzman research (2010), formulated as follows:

$$
B T D=\frac{{\text { Pretax Accounting } \text { Income }_{i t}-\text { Tax }_{\text {Income }}}_{i t}}{{\text { Total } \text { Asset }_{i, t-1}}}
$$

\section{Abnormal Book-Tax Differences}

Abnormal book-tax differences refer to measurements in Desai and Dharmapala (2006), calculating by realizing total book tax differences on total accrual. The residual value obtained from the regression result would be used as a proxy to measure tax avoidance. Abnormal BTD is formulated as follows:

Residual from BTD $/ T A_{i t}=\beta T A_{i t}+\beta \mu_{i}+e_{i t}$ In which:

$$
\begin{aligned}
& \text { BTD }_{\text {it }}= \begin{array}{l}
\text { Book tax difference of company } \\
\text { i in } \mathrm{t}-\text {-year }
\end{array} \\
& \text { TA }_{\text {it }}= \text { Total accrual of company } \mathrm{i} \text { in } \mathrm{t}- \\
& \text { year } \\
&= \begin{array}{l}
\text { (profit before tax }- \text { operating } \\
\text { cash flow) } / \text { total asset } \mathrm{t}-1
\end{array} \\
&= \begin{array}{l}
\text { The average value of company } \mathrm{i} \\
\text { residual in years } \mathrm{t} \text { of the }
\end{array} \\
& \mu_{\mathrm{i}} \quad \begin{array}{l}
\text { equation abnormal book tax } \\
\text { difference in the period of study }
\end{array} \\
& \quad= \begin{array}{l}
\text { The deviation value of the } \\
\text { average of company } \mathrm{i} \text { residual }
\end{array}
\end{aligned}
$$

\section{Tax Sheltering}

Tax sheltering is a tax planning designed to avoid taxes without any economic risk or loss. It could be obtained from the sum of $\mu \mathrm{i}$ and $\varepsilon i, t$, the results of the abnormal equation regression of BTD, refering to the measurements of Desai and Dharmapala (2006).and formulated as follows: 
In which:

$$
T S_{i t}=\mu_{i}+\varepsilon_{i t}
$$

$$
\begin{aligned}
& \mathrm{TS}_{\mathrm{it}}=\text { Tax Sheltering } \\
& \mu_{\mathrm{i}}=\text { The average value of company } \mathrm{i}
\end{aligned}
$$

4. Composite Measure of Tax Avoidance (CMTA)

Composite measure of tax avoidance is a composite value of three measurements of tax avoidance above (Book Tax Difference (BTD), Abnormal BTD and Tax Shelter) to measure corporate tax avoidance.

Each value of the tax avoidance measurement for all companies is calculated by the percentile rank from each sample that shows the position of the level of corporate tax avoidance, and CMTA value of each company would emerge from the average of the total percentile rank. The higher the CMTA value is, the higher the indication of tax avoidance would be.

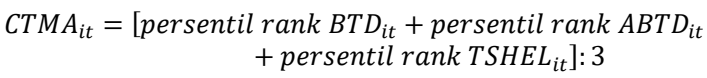

Independent variables used to influence the dependent variable, and those are thin capitalization and executives' characteristics.

\section{1) Thin capitalization}

Thin capitalization is a company practice whose assets are funded by higher debt levels and lower levels of esquity in its capital structure (Kurniawan, 2015:241). The position of thin capitalization is figured out by utilizing a safe harbor test, which involves the calculation of safe harbor debt amounts (SHDA). This model is also used by Taylor \& Richardson (2012) in his research when calculating thin capitalization. Below could describe the steps for each variable used to measure the SHDA, but the ratio of debt and capital following the Minister of Finance Regulation Number 169/PMK.010/2015:

SHDA $=$ (the average of total asset - non- IBL) $\times$ 80\% In which:

- Non-IBL (Interest-Bearing Liabilities) are obligations of non-interest companies, a liability that has relation to interest. MAD could be figured out as follows:

$$
\mathrm{MAD} \text { ratio }=\frac{\text { the average of debt }}{\text { Company SHDA }}
$$

- Average debt is the amount of debt with the company interest in the t-period

The ratio of MAD (maximum amount debt) is calculated according to the equation of thin capitalization. A company whose MAD ratio is more than the equation is considered to be potentially non-compliant with the provision of thin capitalization because the average debt level exceeds its SHDA level.

2) Executives' Characteristics

Low (2006) states that a company leader in performing his duties has two different characters in decision-making, namely risk taker and risk averse. In accordance with Butje and Elisa Tjondro (2014), to look at the traits of the leader and to assess how brave the company executives in taking risks can be seen by looking at corporate risk. 
Paligorova (2010) measures corporate risk by standard deviation equation from EBITDA (earning before income tax, depreciation and amortization) divided by total assets of the company. The high level of corporate risk will show the bias of executives, risk taking or risk averse. Corporate risk is formulated as follows:

$$
\text { CRISK }=\sqrt{\sum_{T-1}^{T}\left(E-1 / T \sum_{T-1}^{T} E\right)^{2} /(T-1)}
$$

The double regression equation could be formulated below:

Regression model:

$$
\operatorname{TAVO}_{i t}=\alpha_{0}+\beta_{1} \operatorname{THIN}_{i t}+\beta_{2} \text { CRISK }_{i t}
$$

Information:

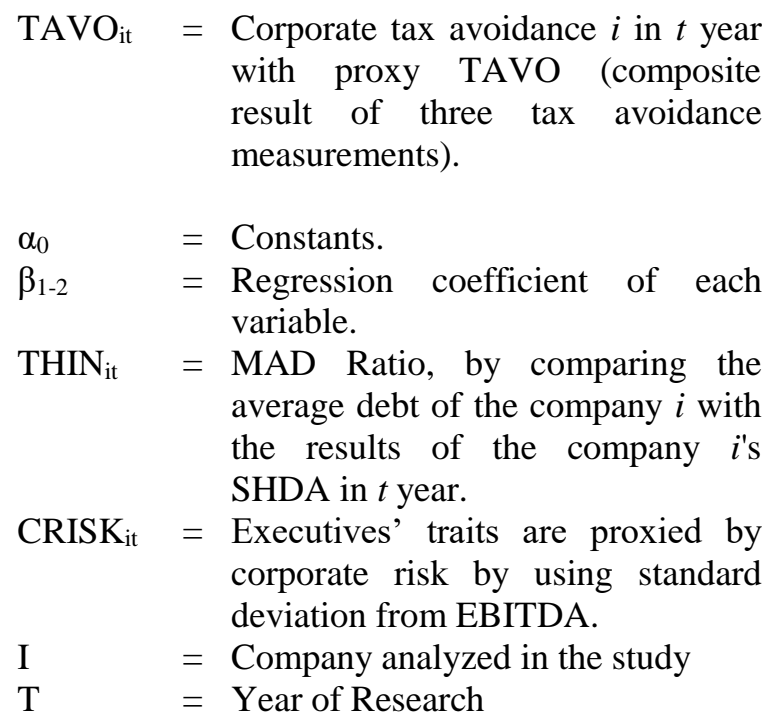

\begin{tabular}{|c|c|c|c|c|c|}
\hline Variabel & $\mathrm{N}$ & Min & Max & Mean & $\begin{array}{c}\text { Std. } \\
\text { Deviation }\end{array}$ \\
\hline THIN & 190 & .1263 & 2.7698 & .626942 & .3374377 \\
\hline CRISK & 190 & .0046 & .4880 & 080089. & 0677998. \\
\hline TAVO & 190 & .0230 & 1.0000 & .523830 & .2760263 \\
\hline $\begin{array}{l}\text { ValidiN } \\
\text { (listwise) }\end{array}$ & 190 & & & & \\
\hline
\end{tabular}

The data analysis method for answering the problem formulation is a descriptive statistical analysis and regression analysis by using SPSS version 22.

\section{ANALYSIS AND DISCUSSION Description of Research Variables}

Table 2. Descriptive Statistics

Source: data processed by SPSS (Descriptive Statistics)

In accordance with table 4.1, the first independent variable, thin capitalization, measured by the ratio of MAD (maximum amount debt) and symbolized by THIN, has a mean value of 0.6269 or $63 \%$. It shows that the average level of the company thin capitalization yields $63 \%$ of the total sample. The minimum value of THIN in the research sample is 0.1263 or $13 \%$ belonging to Mandom Indonesia Tbk., in 2011, meanwhile the maximum value arises from Jembo Cable Company Tbk., in 2011 for 2.7698 or $277 \%$.

The executives' characteristics as the second independent variable, measured by corporate risk and symbolized with CRISK, has a mean value of 0.0800 or $8 \%$. It means that the average level of executives' characteristics is $8 \%$ of the total sample. Concerning the sample, the minimum value of CRISK is 0.0046 or $0.5 \%$ by Ricky Putra Globalindo Tbk., in 2013. On the other hand, the maximum value of CRISK is 0.4880 or $49 \%$ by Mayora Indah Tbk., in 2015 .

Table 4.1 denotes the research dependent variable, tax avoidance, which is measured using the composite value of Book Tax Difference 
(BTD), Abnormal BTD, and Tax Sherltering, and symbolized by TAVO, has a mean value of 0.5238 or $52 \%$. It means that the average level of tax avoidance is $52 \%$ of the total sample. The minimum value of TAVO is 0.0230 or $2 \%$ by Jembo Cable Company Tbk., in 2012, and the maximum value of TAVO is 1,000 or $100 \%$ by Unilever Indonesia Tbk., in 2015.

\section{Significance Test of Parameter of Individual Data (Statistical Test t)}

Statistical test $t$ is conducted to find out how much significance level or influence of each independent variable are in explaining the variation of the dependent variables (Ghozali, 2013:97). The level of significance employed in this t-test is $5 \%(0.05)$, meaning the risk of mistakes in decision making is $5 \%$. The significance test of individual data parameter results as follows:

Table 3. The Result of Significance Test of

\begin{tabular}{|c|c|c|c|c|c|}
\hline \multirow{3}{*}{ Model } & \multicolumn{5}{|c|}{ Parameter of Individual Data } \\
\hline & \multicolumn{2}{|c|}{$\begin{array}{c}\text { Unstandardized } \\
\text { Coefficients }\end{array}$} & \multirow[t]{2}{*}{$\begin{array}{l}\text { Standardized } \\
\text { Coefficients }\end{array}$} & \multirow[t]{2}{*}{$\mathrm{T}$} & \multirow[t]{2}{*}{ Sig } \\
\hline & $\mathrm{B}$ & $\begin{array}{l}\text { Std. } \\
\text { Error }\end{array}$ & & & \\
\hline (Constant) & .474 & .044 & & 10.695 & .000 \\
\hline THIN & .107 & .056 & .130 & 1.917 & .047 \\
\hline CRISK & 1.453 & .277 & .357 & 5.251 & .000 \\
\hline
\end{tabular}

a. Dependent Variable: TAVO

Source: data processed by SPSS (Coefficients)

On table 4.2, it indicates thin capitalization (THIN) has a significance probability value of 0.047 and the executives' characteristics (CRISK) exhibits the value of 0.000. Both of them have a significance probability value which is less than the significance level determined of 0.05 or $5 \%$, meaning the these two independent variables influence tax avoidance (TAVO).

\section{The Discussion of the Result}

The Influence of Thin Capitalization to Tax Avoidance

Regarding to the results of hypothesis testing on Table 4.2 , the testing of thin capitalization by using the MAD (maximum amount debt) ratio to tax avoidance has a regression coefficient of 0.107 and a significance probability value of 0,047 or less than the specified level of 0.05 or $5 \%$. The coefficient indicates the existence of positive relationship between thin capitalization and tax avoidance which means that the higher the MAD ratio is, the higher tax avoidance would be, or vice versa. The result also depicts the practice of thin capitalization by companies influences tax evasion. To sum up, the first hypothesis that states thin capitalization has a positive effect on tax avoidance can be accepted.

In addition, the result points that tax avoidance practice through making debt structure much larger than capital (thin capitalization) is one of the attempts to minimize the corporate tax burden. The emergence of thin capitalization is due to the existence of rules in taxation provisions that gives different treatment to interest and dividend as a form of return on share investment in the company. Payment of interest on loans is a deductible expense to calculate the amount of taxable income, while dividend payments are costs that cannot be diminished. 
The theory supporting the first hypothesis is the theory of planned behavior, describes that the company has certain intentions to maximize its profits by minimizing tax burden. Due to the effort, the company commits thin capitalization by increasing the interest loans obtained from shareholders. Companies that receive all interestbearing loans will be burdened with deductible interest costs in calculating the taxable income. The smaller the taxable income is, the smaller the tax burden would be.

Thin capitalization generally requires partners or affiliation as its debt financing effort in countries with higher tax rates in order to obtain greater reduction in the basis of imposition. The steps the government takes in handling the practice of thin capitalization is the issuance of the Decree of Minister of Finance Number 1002/KMK.04/1984 concerning the magnitude of ratio of debt to capital, which has been previously deferred by the Decree of Minister of Finance Number 254/KMK.01/1985. Subsequently, considering a greater number of companies utilizing corporate financing through interest debt, the government issued Regulation of the Minister of Finance Number 169/PMK.010/2015 with the amount of debt to equity ratio (DER) set at the highest of 4:1.

These following points are loan fees, included in the costs borne by the company related to the loan it receives:
a. Loan interest.
b. Discount or premium related to loans.
c. Additional costs for obtaining a loan.

d. Financial expenses in finance leases.

e. The cost of compensation for the guarantee in returning the debt.

f. The difference of an exchange rate obtained from loans in foreign currencies.

The ratio value of debt with capital owned by the company is not permitted to exceed the stipulated limit. If the magnitude of the ratio exceeds the specified limit, the costs on the loan may only be charged according to safe harbor limit. The table below would exhibit the limit of ratio between debt and equity or debt equity ratio (DER) in several countries:

Table 4. The Provisions of Thin Capitalization Rules in Some Countries

\begin{tabular}{lcc}
\hline \multicolumn{1}{c}{ Country } & Limit of Ratio & $\begin{array}{c}\text { Requirement of } \\
\text { Ownership }\end{array}$ \\
\hline Japan & DER $3: 1$ & Ownership $<50 \%$ \\
Australia & $D E R 3: 1$ & Ownership $<15 \%$ \\
Canada & DER $2: 1$ & Ownership $>25 \%$ \\
United States & & Ownership 50\% \\
of America & DER $1: 1$ & .
\end{tabular}

Source: Ning Rahayu (2010)

Thin capitalization rules applied in Indonesia are still larger with the limit of ratio of debt to capital of $80 \%$, compared to the other countries which generally sets $75 \%$. This has prompted companies to continue to practice thin capitalization because of provisions that are deemed not to burden the company to tax avoidance.

The results are consistent with research by dilakukan Taylor and Richardson (2012) which shows that companies that have a greater debt to capital ratio will tend to be made to optimize profits from minimizing corporate income tax. 
However, Ismi andLinda (2016) in their study argues that the interest-based debt restrictions imposed by the company do not affect the company actions due to the lack of tax processing practices with optimized company debt ownership.

\section{The Influence of Executives' Characteristics}

\section{to Tax Avoidance}

On Table 4.2, the testing of the executives' characteristics by using corporate risk to tax avoidance has a regression coefficient of 1.453 and a significance probability value of 0.000 or smaller than the determined significance level which is 0.05 or $5 \%$. The regression coefficient shows the existence of a positive relationship with tax avoidance which means that the greater the risk of the company is, the greater tax avoidance would be, or vice versa. The results of testing indicates that the characteristics of the executives influence tax avoidance. It can be concluded if the second hypothesis is accepted.

Additionally, the increase or decrease in corporate risk describes the executives' characteristics. The high value of corporate risk (CRISK) exhibits the risk taker as traits which has a large tendency to avoid tax compared to the value of corporate risk (CRISK), as evidenced in the following data:

Table 5. The Minimum and Maksimum values of Corporate Risk (CRISK) \& the Value of TAVO

\begin{tabular}{lcc}
\hline \multicolumn{1}{c}{ CompanyName } & CRISK & TAVO \\
\hline Ricky Putra Globalindo Tbk. & 0,0046 & 0.31467 \\
Mayora Indah Tbk. & 0,4880 & 0.98900 \\
\hline
\end{tabular}

Source: data processed by authors.
Ricky Putra Globalindo Tbk., has CRISK value of 0.0046 with TAVO of 0.3146 which means risk averse traits dominantly exist, to take less tax avoidance actions. Whereas Mayora Indah Tbk., possesses the largest CRISK value of 0.4880 with a TAVO of 0.9890 indicating that the executives' characteristics is considered risk takers by highly doing tax avoidance actions.

Moreover, corporate executives have influence in making risky decisions to obtain profits for the company. One of the ways used to maximize company profits is to minimize the tax burden or to divert income through tax avoidance. Company executives place trustees whose expertises are to observe and create tax avoidance schemes according to what executives expect. Shortly, the executives do not directly take part in these actions.

Based on the description above, it can be concluded that the results of the research denoting that the executives' characteristics influence tax avoidance. It supports the research of Dyreng et al. (2010) which argues that the executives' characteristics has a role in supporting tax avoidance actions, and Budiman et al. (2012) notes that if the company executives are risk takers, the higher rate of avoidance would be taken.

\section{CONCLUSIONS}

1. Thin capitalization has a positive effect on tax avoidance, in which the higher the practice thin capitalization is conducted, the higher tax avoidance actions would be executed. It 
means that manufacturers that commit thin capitalization can reduce interest payments at a higher level against reported taxable income. This causes the tax burden to be smaller and more efficient, followed by a higher level of tax avoidance

2. Executives characteristics positively influence tax avoidance, meaning that the greater corporate risk indicates, the more risk taker traits belong to the executives, the higher level of tax avoidance would be. Manufacturers with high corporate risk value represent the condition whereby the risk-taker executives' characteristics have a tendency to prefer high risk with high expected profit levels, therewith higher tax avoidance to minimize the tax burden.

\section{Limitation}

Limitation in research consists of as follows:

1) The period of the study only uses 5 (five) years, emerging to limited research data.

2) The research population only uses manufacturers and, thus, the research population are not broad enough.

3) The practice of international tax avoidance which is used as variable is limited to the practice of thin capitalization.

\section{Suggestions}

Based on the research conducted, the following are suggestions that the study could contribute:

1) The study indicates that thin capitalization affects tax avoidance, and Directorate General of Taxes is expected to review tax regulations related to the Regulation of the
Minister of Finance Number 169/PMK.010/2015. The occurrence happens because the limit of the ratio between debt and capital set in Indonesia is relatively larger than the limits set by other countries. Hence, most companies tend to avoid taxation by increasing their interest-bearing debt.

2) The result of the study shows the executives' characteristics influence tax avoidance. Therefore, the executives are expected to pay attention to the magnitude of the corporate risk before setting a policy. It purposes to facilitate the company in deciding the level of risk, and thus, it can yield a policy concerning optimal tax avoidance.

3) For further research, the study recommends to use other international tax avoidance practices, so that it is possible to find different influences besides the practice of thin capitalization such as transfer pricing, treaty shopping, and controlled foreign corporation (CFC).

\section{REFERENCES}

Arifin, N. Z. (2014). BEPS Dalam Kerangka Kerja Sama G20 Dan Implementasinya Kepada Indonesia. 13: 1-27.

Azwar, S. (2013). Sikap Manusia: Teori Dan Pengukurannya. 2nd ed. Pustaka Pelajar.

Bank Indonesia. (2014). Laporan Perekonomian Indonesia (Indonesian Economy Report). http://www.bi.go.id/id.

Budiman, J., \& Setiyono. (2012). Pengaruh Karakter Eksekutif Terhadap Penghindaran Pajak (Tax Avoidance). SNA XV Banjarmasin: 1-22.

Copyright @ 2019 AKRUAL: Jurnal Akuntansi 
Butje, S., \& Tjondro, E. (2014). Pengaruh Karakter Eksekutif Dan Koneksi Politik Terhadap Tax Avoidance. Tax \& Accounting Review 4(2): 1-22.

Deddy. (2015). ICIJ: Indonesia Urutan Ke-95 Skandal Swiss Leaks. CCN Indonesia. http://www.cnnindonesia.com.

Desai, M. A., Foley, C. F., \& Hines, J. R. (2006). The Demand for Tax Haven Operations. Journal of Public Economics 90(3): 51331.

Desai, M. A., \& Hines, J. R. 2002. Expectations and Expatriations: Tracing The Causes and Consequences of Corporate Inversions. Nber Working Paper Series Expectations: $1-43$.

Dyreng, S. D., Hanlon, M., \& Maydew E. L. (2010). The Effects of Executives on Corporate Tax Avoidance. Accounting Review 85(4): 1163-89.

Ghozali, I. (2013). Aplikasi Analisis Multivariat Dengan Program IBM SPSS 21. 7th ed. Semarang: Universitas Diponegoro.

Hanlon, M., \& Heitzman, S. (2010). A Review of Tax Research. Journal of Accounting and Economics 50(2-3): 127-78.

Hartono, J. (2013). Metodologi Penelitian Bisnis. 6th ed. Yogyakarta: BPFE.

International Consortium of Investigative Journalist. (2015). Top Countries Swiss Leaks.

https://projects.icij.org/swissleaks/countries/rankings\#money.

Ismi, F., \& Linda. (2016). Pengaruh Thin Capitalization, Return On Asset, dan Corporate Governance Pada Perusahaan Jakarta Islami Index ( JII ). Jurnal Ilmiah Mahasiswa Ekonomi Akuntansi (JIMEKA) 1(1): 150-65.

Jacob, F. (2014). An Empirical Study of Tax Evasion and Tax Avoidance: A Critical Issue in Nigeria Economic Development. Issn 5(18): 22-27. www.iiste.org.
Kementerian Keuangan. (2015). PMK169/PMK.010/2015 Penentuan Besarnya Perbandingan Antara Utang Dan Modal Perusahaan Untuk Keperluan Penghitungan PPh.

Kurniawan, A. M. (2015). Pajak Internasional Beserta Contoh Aplikasinya. kedua. Bogor: Ghalia Indonesia.

Low, A. (2006). Managerial Risk-Taking Behavior and Equity-Based Compensation. The Journal of the American Taxation Association 23(1): 1-19.

Ngadiman \& Puspitasari, C. (2014). Pengaruh Leverage, Kepemilikan Institusional, Dan Ukuran Perusahaan Terhadap Penghindaran Pajak (Tax Avoidance) Pada Perusahaan Sektor Manufaktur Yang Terdaftar Di Bursa Efek Indonesia 2010-2012. Jurnal Akuntansi XVIII(3): 408-21.

Paligorova, T. (2010). Corporate Risk Taking and Ownership Structure Corporate Risk Taking and Ownership. Bank of Canada Working Paper: 1-41.

Penman, S. H., Richardson, S. A., \& Tuna, I. (2007). The Book-to-Price Effect in Stock Returns: Accounting for Leverage. Journal of Accounting Research 45(2): 427-67.

Rahayu, N. (2010). Evaluasi Regulasi Atas Praktik Penghindaran Pajak Penanaman Modal Asing. Jurnal Akuntansi dan Keuangan Indonesia 7(1): 61-78.

Suandy, E. (2016). Perencanaan Pajak. Keenam. Jakarta: Salemba Empat.

Sudiarta, I. W. (2016). Panama Papers Dan Praktik Penghindaran Pajak. CCN Indonesia.

Sugiyono. (2015). Metode Penelitian Kuantitatif, Kualitatif, Dan R\&D. Bandung: Alafabeta.

Taylor, G., \& Richardson, G. (2012). International Corporate Tax Avoidance Practices: Evidence from Australian Firms. International Journal of Accounting 47(4): 469-96.

Zain, M. (2008). Manajemen Perpajakan. 3rd ed. Jakarta: Salemba Empat. 
AKRUAL: Jurnal Akuntansi, volume 10, issue 2, April 2019 (119-134) 